MELVILLE WESTON FULLER

DAVID JOSIAH BREWER

Memorial Note ${ }^{1}$

Thrice within a period of less than nine months, as the hand of Death reached forth, has its finger pointed to a member of the Supreme Court of the United States. On October 14, 1909, Mr. Justice Peckham died at his home in Altamont, near Albany, N. Y.; on March 28, 1910, Mr. Justice Brewer died at his home in Washington, and less than four months thereafter, amidst the festivities of our national holiday, on the Fourth of July, came the news of the sudden death of the Chief Justice at the summer home which he had made at Sorrento in his loved and native State of Maine.

Never before in the history of the court has a President been called upon to fill so many vacancies in so short a period.

All of these men were eminent jurists; all had been on the bench for many years and had gained the confidence of the country. Each had lived beyond the allotted term of three score years and ten, and, under the law, might have laid down the burden of his judicial duties; each however had continued to discharge the functions of his high office from an equally high sense of duty. Mr. Justice Peckham was nearly 71, Mr. Justice Brewer nearly 73 and the Chief Justice was over 77 years of age. Each had demonstrated after he had reached the age of elective retirement that he was still in full mental vigor and strength.

The Chief Justice and Mr. Justice Brewer both died very suddenly. Each was apparently in good health a few hours before the end, and the news of his death came as a shock, not only to the country, but to his family and to his colleagues.

For more than twenty years these two men were closely associated as members of the same court; seated next to each other for more than a third of that time, their intercourse was of the closest. They had many thoughts in common; though on occasions they differed, they were generally found aligned together when the court divided. And so it was when one went, the other quickly followed. Like Saul

1 The Journal is indebted, for this memorial note, to the courtesy of Charles Henry Butler, Esq., Reporter of the Decisions of the Supreme Court of the United States. - ED. 
and Jonathan, they were pleasant in their lives and in their death they were not divided.

The lives of Chief Justice Fuller and Mr. Justice Brewer and the numerous able and important decisions rendered by them have been elaborately reviewed in many of the journals of the day, and it is only towards their work in connection with international affairs that the few inadequate words that follow will be directed. The brief summaries which appeared in the latest editions of the Congressional Directory, are appended hereto for reference as to some of the conspicuous events of their lives. ${ }^{2}$

2 Melville Weston Fuller, Chief Justice of the United States, was born in Augusta, Me., February 11, 1833; was graduated from Bowdoin College in 1853; studied law, attended a course of lectures at Harvard Law School, and was admitted to the bar in 1855; formed a law partnership in Augusta, Me., and was an associate editor of a Democratic paper called The Age; in 1856 became president of the common council, and served as city solicitor; removed to Chicago, Ill., in 1856, where he practiced law until appointed Chief Justice; in 1862 was a member of the State constitutional convention; was a member of the State legislature from 1863 to 1865 ; was a delegate to the Democratic national conventions of $1864,1872,1876$, and 1880 ; the degree of $L L$. D. was conferred upon him by the Northwestern University and by Bowdoin College in 1888, by Harvard in 1890, by Yale and Dartmouth in 1901; was appointed Chief Justice April 30, 1888, confirmed July 20,1888, and took the oath of office October 8, same year. He was chancellor of Smithsonian Institution; chairman trustees Peabody Education Fund; vice-president John F. Slater Fund; member board of trustees of Bowdoin College; one of the arbitrators to settle boundary line between Venezuela and British Guiana, Paris, 1899; member permanent court of arbitration, The Hague; member arbitral tribunal in the matter of the Muscat Dowhs, The Hague, 1905 ; received thanks of Congress December 20, 1889.

David JosIan Brewer, Associate Justice of the United States Supreme Court, was born in Smyrna, Asia Minor, June 20, 1837; was the son of Rev. Josiah Brewer and Emilia A. Field, sister of David Dudley, Cyrus W., and Justice Stephen J. Field; his father was an early missionary to Turkey; was graduated from Yale College in 1856 and from the Albany Law School in 1858; established himself in his profession at Leavenworth, Kan., in 1858, where he resided until he removed to Washington to enter upon his duties; in 1861 was appointed United States commissioner; during 1863 and 1864 was judge of the probate and criminal courts of Leavenworth county; from January, 1865, to January, 1869, was judge of the first district court of Kansas; in 1868 and 1870 was county attorney of Leavenworth; in 1870 was elected a justice of the Supreme Court of his State, and re-elected in 1876 and 1882 ; in 1884 was appointed judge of the Circuit Court of the United States for the eighth district; was appointed to the Supreme Court, to succeed Justice Stanley Matthews, deceased, in December, 1889, and was commissioned December 18, 1888 ; president 
Both of these eminent jurists were vice-presidents and members of the Executive Council of the American Society of International Law. Appropriate action has been taken in regard to the death of Mr. Justice Brewer, ${ }^{3}$ and will be taken in regard to that of the Chief Justice. ${ }^{4}$ Each had taken an active interest in its affairs, had participated in the meetings of the Society and were among its valued members. Nay more! Each in his speech and by his acts had done his valiant part in carrying forward the greatest work of modern times - that of establishing peaceful methods for the settlement of international disputes. Each had served on international tribunals, and each in both national and international courts had rendered decisions on important questions of international law - decisions which will stand as monuments to

of the Venezuelan Boundary Commission, appointed by President Cleveland; member of Arbitration Tribunal to settle boundary between British Guiana and Venezuela; orator at bicentennial, Yale University, 1901; president International Congress of Lawyers and Jurists, St. Louis, 1904 ; received degree of LL. D. from Iowa College, Washburn College, Yale University, State University of Wisconsin, Wesleyan University, Middletown, Conn.; University of Vermont, and Bowdoin College.

3 At the meeting of the bar and officers of the Supreme Court of the United States in memory of Mr. Justice Brewer, held on April 30, 1910, Mr. George Grafton Wilson, a member of the American Society of International Law, made the following remarks and placed upon the record the resolution therein referred to which had been adopted by the Society.

"The American Society of International Law has been in session in Washington since Thursday of this week. During this period we have missed very keenly the genial and inspiring presence of our distinguished vice-president, Justice Brewer. When it was learned that you would gather here this noon to pay tribute to his memory, the Society adjourned to join with you in that tribute. We recognize his distinguished service to a branch of law somewhat different from those branches which have already been particularly mentioned to International Law, which has gained greatly in importance during the period which Justice Brewer has served in this great court. Since 1890 cases have become more and more frequent, involving such legal principles as those in which we are specially interested. The Society, particularly regardful of his services to international justice, adopted the following resolution:

"The American Society of International Law desires to record, with profound sense of loss, the death of Hon. David J. Brewer, since 1889 a justice of the Supreme Court of the United States, in 1896 president of the Venezuela Boundary Commission, in 1899 a member of the Venezuela Arbitration Tribunal, from its foundation a vice-president and loyal supporter of the American Society of International Law."

4 There has been no meeting of the Society or of the Executive Council since the death of Chief Justice Fuller. 
mark the way, and as beacon lights to guide the course, of those who must decide the cases arising in the future.

It is by such decisions, elucidating the law in each particular case as it comes before an international tribunal, that gradually a great body of international law will be built up exactly in the same manner as the common law, as now applied, has been the gradual development of centuries of the best legal thought of the Anglo-Saxon race.

In his lecture on the "Value of Authority of Adjudged Cases," Mr. Justice Miller says that while the main value of such authorities may be in the character of the court deciding the cases, that value may be very much enhanced by the standing of the judge delivering the opinion. Judged from that standpoint, surely the opinions of these two eminent members of the great court whose bench they adorned for so long a period must always have a predominant value, and will be cited not only as decisions of that court but also as individual utterances of those best qualified to speak in regard to the matters involved.

It will, of course, be impossible to refer to more than a few of the many hundreds of opinions delivered by them in the course of their judicial careers. ${ }^{5}$ Only a few can be selected and those will be amongst their recent utterances; not because they are the most important, but because they are those with which the writter is most familiar.

Before referring to the opinions delivered in the national courts it will be proper to make a brief reference to the instances in which they participated as judges in international tribunals.

In December 1895, acting upon the Venezuelan message of President Cleveland which so startled bath this country and Great Britain, the Congress passed an Act appointing a commission to investigate the boundary line between Venezuela and Great Britain. This was done in order that the United States might not demand for Venezuela any more than that country was entitled to.

The commission as organized, consisted of $\mathrm{Mr}$. Justice Brewer as president, Chief Justice Alvey of the Court of Appeals of the District of Columbia, Mr. Frederic R. Coudert of New York, Mr. Daniel C. Gilman, President of Johns Hopkins University, and Mr. Andrew D. White, President of Cornell University. It entered upon the dis-

5 For an interesting review of some of the decisions of Mr. Justice Brewer, see the remarks of the Attorney-General presenting resolutions on his death to the Supreme Court of the United States on May 31, 1910, and which will appear in Volume 218, United States Reports. 
charge of its duties, but before the investigation was completed, the British foreign office realized that the United States was in earnest in the intention, which it had expressed through President Cleveland and Secretary of State Olney, to resist all encroachments and to make a vigorous stand on behalf of Venezuela and of the Monroe Doctrine. Lord Salisbury receded from his refusal to arbitrate the boundary question and, in February 189\%, a treaty of arbitration was entered into between Great Britain and Venezuela, by which the whole subject was referred to an international tribunal of five members, two of whom were to be appointed by the Supreme Court of the United States, two by the Supreme Court of Great Britain, the treaty providing that the arbitrators so appointed might be members of those courts respectively; the fifth, was to be appointed either by the four others, or if they could not agree (as was the case) by the King of Norway and Sweden, who subsequently appointed the eminent Russian jurist, Frederic de Martens.

The treaty gave a wide scope, but laid down certain rules to be regarded as principles of international law to guide the arbitrators in regard to prescriptive title and occupancy of territory.

The Supreme Court of the United States named Chief Justice Fuller and, as the work of the commission had been suspended, Mr. Justice Brewer. The Supreme Court of Great Britain named Baron Hershel, who died before the arbitration took place, and, in his place, Lord Chief Justice Russell of Killowen, and Sir Richard Henn Collins, Lord Justice of Appeals.

The tribunal met in Paris in the summer of 1889 , and on October 3 , after listening to arguments of eminent counsel, including ex-President Harrison on behalf of Venezuela, and Sir Richard Webster, on behalf of Great Britain, made an award finally settling a boundary controversy which had periodically threatened the amicable relations of three nations during more than half a century. The award was acquiesced in by both of the principals to the controversy, and the fact that the extreme claims of Great Britain were not allowed, but a large portion of the territory claimed by the weaker nation was, after an exhaustive examination by five eminent jurists, saved to it, was a complete vindication of the attitude assumed by the United States. It was a distinct triumph for the cause of arbitration to which Chief Justice Fuller and Mr. Justice Brewer largely contributed, by devoting so much of their time, energy and ability. 
The Venezuelan arbitration was concluded prior to the establishment of the Hague Court, and, when in 1899, the First Peace Conference established the Permanent Court and provided for the appointment of four of its members by each of the participating powers, President McKinley promptly appointed eminent representatives of this country, heading the list with the Chief Justice of the United States.

of the nearly two hundred jurists appointed to that court by the participating powers since it was first organized, including those added after the accession, in 1907, of the South American powers, less than twenty-five have been called upon to act in the eight arbitral proceedings that have come before it.

During the ten years that his name was on the list of judges, Chief Justice Fuller was requested to act no less than three times, but was only able to serve on one occasion. He was unable to act at the instance of the Japanese Government in the Window Tax case, and, just before his death, he had been asked to act as arbitrator in a case between two American powers which will probably be referred to that court or otherwise settled by arbitration.

He was, however, named as one of the judges, and accepted and served, in the case of the Muscat Dhows in 1904.

Differences having arisen between Great Britain and France as to the right of the latter to grant the protection of its flag to vessels belonging to subjects of the Sultan of Muscat, and great trouble having arisen under the Brussels Slave Trade Act, by reason of the claims to immunity from search made by Muscat owners of Dhows flying the French flag, the matter was referred to a Hague tribunal of three members. Great Britain appointed the Chief Justice of the United States, France appointed Jonkherr Savornin-Lohman, an eminent professor of Holland; Prof. Heinrich Lammasch of the University of Vienna was named as third arbitrator and president of the tribunal. Both of the Chief Justice's colleagues in the Muscat Dhows case were, at the time of his death, sitting as members of the court at The Hague on the fisheries dispute between this country and Great Britain.

The court sat at The Hague in the summer of 1904 and considered a number of intricate questions involving the rights and duties under the Brussels Slave Trade Act of 1890 , as well as other treaties and declarations relating to the suppression of slave traffic, to the sovereignty of the Sultan of Muscat and the definition of the word "protected" (protegé) as used in the treaties and acts. It pronounced an arbitral 
sentence by which all of those questions were satisfactorily settled, and the limitations as to the power to grant privileges of its flag to native vessels by a signatory to the Brussels Act were carefully defined. The sentence also involved the extent to which a treaty exemption from search in the homes of natives of a protected state extended to their vessels.

It was not only as judges of international tribunals, however, that Chief Justice Fuller and Mr. Justice Brewer rendered decisions and delivered opinions on questions of international law. On more than one occasion each has stated in his judicial utterances, that "international law is a part of our law and the Supreme Court of the United States, sitting, as it were, as an international, as well as a domestic, tribunal, applies federal law, State law and international law as the exigencies of the case demands." 8

It frequently happens therefore that in cases before the Supreme Court questions of international law arise and are decided. This is especially true in cases between States over which the Constitution wisely gave that court jurisdiction, thus not only creating a court of international justice for the States of this Union, but one which may well serve as an example for that court of arbitral justice which eventually must be established, and whose jurisdiction will extend over the sovereign nations of the world.

Among the cases involving questions of international law lately determined and in which both the Chief Justice and Mr. Justice Brewer participated, one or the other delivering the opinion, are those of Kansas v. Colorado, ${ }^{7}$ Virginia v. West Virginia, Louisiana v. Mississippi, ${ }^{\mathrm{s}}$ Wright v. Henkel, ${ }^{8}$ prize cases of the Spanish War, and the cases involving the construction of the treaty of peace that terminated that unfortunate but unavoidable episode.

The case of Kansas v. Colorado, brought by the plaintiff State to restrain the defendant from diverting waters of the Arkansas river, was twice before the court. The first occasion was on the argument of Colorado's demurrer to the jurisdiction, which was overruled, the Chief Justice writing the opinion (185 U. S. 125). In answer to Colorado's

- Mr. Justice Brewer in Kansas v. Colorado, 206 U. S. 46, p. 97, citing Chief Justice Fuller in an earlier decision in the same case 185 U. S. 125, p. 146.

$\tau$ Printed in Journat, $1: 216$.

8 Printed in Journal, $1: 204$.

- Printed in JoubNal, $1: 202$. 
contention that "only those controversies are justiciable in this court which, prior to the Union would have been just cause for reprisal by the complaining State and that according to international law reprisal can only be made when a positive wrong has been inflicted or rights stricti juris withheld" he asked:

But when one of our States complains of the infliction of such wrong or the deprivation of such rights by another State, how shall the existence of cause of complaint be ascertained, and be accommodated if well founded? The States of this Union cannot make war upon each other. They cannot "grant letters of marque and reprisal." They cannot make reprisal on each other by embargo. They cannot enter upon diplomatic relations and make treaties. * * * The publicists suggest as just causes of war, defense, recovery of one's own, and punishment of an enemy. But as between States of this Union, who can determine what would be a just cause of war? And, applying the principles settled in previous cases, we have no special difficulty with the bare question whether facts might not exist which would justify our interposition.

He disposed of the suggested difficulty as to determining the law of the case by declaring that in such cases the court sat as it were as an international as well as a domestic tribunal.

The demurrer was overruled and when the case came again to the court Mr. Justice Brewer wrote the opinion. He reiterated the above proposition, citing the remarks of the Chief Justice to the effect that the court in such a case sat as an international court and applied international law. The proposition that a State might have a right to prevent another State from wholly diverting the water of interstate streams was sustained, but the court was of opinion that Kansas had not demonstrated that it had been sufficiently deprived of the waters of the river to justify the interposition of the court and the bill was dismissed without prejudice.

When West Virginia became a separate State in 1863, Virginia was heavily indebted on its State bonds, and, in 190\%, after more than forty years of ineffectual negotiations with its offspring to adjust and divide responsibility, it filed its bill in the Supreme Court of the United States to compel West Virginia to assume or pay a portion of that indebtedness. West Virginia demurred on various grounds and denied the jurisdiction of the court. The leading argument for that State was made by Mr. John G. Carlisle, who, like three of the justices participating in the decision, has not lived to see the conclusion of the case.

The Chief Justice after an elaborate statement of the case, sustained the jurisdiction of the court, and, disposing of all the other matters 
raised by it, overruled the demurrer. The case was sent to a master to take testimony and is now before the court for final hearing.

After the "Oyster Wars" in the disputed waters of the Gulf of Mexico, Louisiana filed its bill in the Supreme Court of the United States against the State of Mississippi to determine the boundary line. The Chief Justice delivered an opinion (202 U. S. 1), largely sustaining the contentions of Louisiana and applying the doctrine of the thalweg - the deepest channel. Up to that time, the rule of the thalweg had been applied to rivers, but in this case, the court was (p. 50) " of the opinion that, on occasion, the principle of the thalweg is applicable in respect of water boundaries to sounds, bays, straits, gulfs, estuaries and other arms of the sea," in fact, wherever there is a deep water sailing channel, the rule applies.

The question of prescription was also involved and the Chief Justice reiterated the rule many times held by the court that as

Between States of the Union, acquiescence in the assertion of a particular boundary and the exercise of dominion and sovereignty over the territory within it, should be accepted as conclusive, whatever the international rule might be in respect of the acquisition by prescription of large tracts of country claimed by both.

Wright v. Henkel (1903, 190 U. S. 40), was a habeas proceeding in which the appellant Whitaker Wright sought to be discharged in extradition proceedings on the ground that the statutory crime of forgery by alteration of papers for which he was indicted in England was not a crime at common law or by Act of Congress or by preponderance of the statutes of the States. The Chief Justice, speaking for a unanimous court, declared that treaties must receive a fair interpretation according to the intention of the parties, and, while under the general rule of international law, the offense for which extradition is asked must be made criminal by the law of both countries, in this case, as the act charged was a crime in Great Britain and also in New York, where the arrest was made, the fugitive could be extradited. Wright was remanded, taken back to England, where he pleaded not guilty, was tried and convicted. The trial was a sensational one, and, when the jury brought in a verdict of guilty, Wright immediately swallowed some poison with which he had armed himself in case of such a result, and which was of such powerful potency that he expired in the court room.

War always creates material for courts both national and international, and the Spanish-American War was no exception. While, owing 
to the brief period of belligerency, there were far fewer prize cases than during the Civil War, thase that were brought to the court involved large sums and great principles of law. Chief Justice Fuller delivered the opinion of the court in several of these cases, notably in the Carlos F. Roses (177 U. S. 655), where by a divided court the cargo of the vessel was condemned on the ground that its ante-bellum Spanish character had not been changed by an attempted transfer through endorsement of the bills of lading to a neutral, and, as the vessel was an enemy vessel, the presumption was that the cargo was enemy property also, and this could only be overcome by clear and positive evidence to the contrary. Mr. Justice Brewer joined in a dissent written by Mr. Justice Shiras.

In the Pedro (175 U. S. 354), the Chief Justice spoke for the court for condemnation of a Spanish vessel as not being exempted under the proclamation of April 26, she being in a Spanish, and not an American port, at that time and having been subsequently captured on the high seas. The case was a hard one but a majority of the court considered that the exemption did not apply under the strict rule of war and that the vessel was lawful prize. Mr. Justice Brewer in this case also united in the dissent which was written by Mr. Justice White, the contention of the minority being that under the circumstances the condemnation deprived the vessel of the protection intended by the proclamation, which should have been carried out according to the commendable principles of honesty and humanity now enforced by all civilized nations at the outbreak of war.

In the Benito Estenger (176 U. S. 568) the Chief Justice delivered the opinion, in which Mr. Justice Brewer concurred, affirming the condemnation of a vessel as enemy property including in that term "property engaged in illegal intercourse with the enemy, whether belonging to an ally or a citizen, as the illegal traffic stamps it with the hostile character and attaches to it all the penal consequences."

The Chief Justice delivered the opinions also in the cases of the Manila Prize Money (188 U. S. 254) and in the Infanta Maria Theresa (188 U. S. 283), but they were cases involving the construction of federal statutes concerning distribution of prize money rather than principles of prize under international law.

After the termination of the war by the treaty of peace in December 1898, many questions arose as to the construction of that treaty and the rights of persons and property affected thereby, and in several 
cases of this nature the Chief Justice expressed the views of the court. In Gonzales v. Williams (192 U. S. 1) he announced the unanimous opinion, against the contention of the Government, which had succeeded below, that whatever might be the citizenship status of a woman coming from Porto Rico and who had been excluded from entering the port of New York under the alien immigrant law, she was not an alien and the Act was inapplicable to her case.

In the case of Ponce v. Roman Catholic Church (210 U. S. 296) he showed by an historical review of cases and precedents that the Roman Catholic Church was a juridical person whose property was entitled to protection under the terms of the treaty.

These are but a paltry few of the cases decided and opinions delivered by these two jurists. It would involve an examination of between seventy-five and a hundred volumes of reports to give them all: the few that are cited have been selected to show what broad subjects they were called upon to consider and how they were able to meet the great questions involved as they arose.

It is impossible to attempt to estimate the weight of their utterances and the effect they will have in future years, but it certainly can be said that these men assisted in developing in accordance with good conscience and in the right direction, the great body of legal principles with which they dealt in administering justice between their fellow men, and no one can deny that each fulfilled both in letter and spirit the oath which he took on his accession to the bench "to administer justice without respect to persons, do equal right to the poor and to the rich and to faithfully discharge the duties incumbent upon him."

But there is another phase of the lives of these men which deeply impressed all who knew them intimately. There was a divinely human side to each. The hand that could without a tremor sign the decree that settled the fate in the pending controversy of man or State or nation could yet reach forth and hand a cup of cold water to the least who needed it. There was intellect, but there was heart also; each was a consistent and zealous Christian, in private life as well as in the church; and each held high office in his own denomination.

Each recognized his duty to his fellow man and did his best to fulfil it.

Notwithstanding their arduous labors on the bench each found some time to devote to the affairs of their fellow men. The Chief Justice gave a full quota of attention to the Smithsonian Institution, of which 
he was the chancellor, and to the Peabody Education Fund, of which he was a trustee; Mr. Justice Brewer for years acted as president of the charity organization of our capital city. Each could well and truly have said for himself

\author{
I live for those who love me \\ Who know me well and true, \\ For the Heaven that smiles above me \\ To receive my spirit too. \\ For the wrong that need resistance, \\ For the right that need assistance, \\ For the future in the distance, \\ For the good that I may do.
}

Of all the utterances from the presiding officer of that highest court in the land - and they have been many and have been pronounced in cases of far-reaching importance and involving great principles - none have left a deeper impression on the writer than the words which he uttered with heart-felt and throbbing emotion in response to the remarks of the Attorney-General on presenting the resolutions of the bar on the death of Mr. Justice Brewer. He voiced the sentiments of all those who knew that Justice intimately when he declared "that it was not his magnificent judicial labors but the ineffable sweetness of his disposition that chiefly impressed itself upon us." Surely the same words can apply to the Chief Justice himself, and there can be no words more fitting, as to both of its subjects, with which to close this article than those in which, on the same occasion, the survivor paid a beautiful and affectionate farewell to the loved brother and colleague who had preceded him. "It has been my sad duty," he said in further response to the Attorney-General,

to accept for the court tributes of the bar in memory of the many members of this tribunal who have passed to their reward. As our Brother Brewer joins the great procession, there pass before me the forms of Matthews and Miller, of Field and Bradley and Lamar and Blatchford, of Jackson and Gray and of Peckham, whose works follow them now that they rest from their labors. They were all men of marked ability, of untiring industry, and of intense devotion to duty, but they were not alike. They differed "as one star differs from another star in glory." Their names will remain illustrious in the annals of jurisprudence. And now we are called on to deplore the departure of one of the most lovable of them all.

He died suddenly, but not the unprepared death from which we pray to be delivered. When the unexpected intelligence was conveyed to me I could not but think of Mrs. Barbauld's poem on "Life," and seemed to hear our dear friend exclaim - 
Life! we've been long together,

Through pleasant and through cloudy weather;

'Tis hard to part when friends are dear;

Perhaps 'twill cost a sigh, a tear;

Then steal away, give little warning,

Choose thine own time;

Say not good night, but in some brighter clime

Bid me good morning.

"Even so" - and in the same affectionate spirit let us say of them both - "They rest from their labors and their works do follow them."

\section{THE FOURTH INTERNATIONAL AMERICAN CONFERENCE}

The Fourth International Conference of the American Republics held its meetings in the city of Buenos Aires in July and August. The date of the conference is memorable as coinciding with the celebration of the centenary of Spanish American independence. Among all the features of the celebration of this great historical event there stands out prominently the meeting of representatives of the American republitcs for the discussion of the common interests of all America. The motions of homage and of condolence which were adopted by the conference well express the feeling of a common destiny and the mutual sympathy that animates the republics. The death of the great Chilian statesman and leader, President Montt, as well as the disaster which recently befell Costa Rica, when Cartago was destroyed by an earthquake, gave rise to a spontaneous and dignified expression of the common participation in such sorrows. On the other hand, on the different dates when individual American republics commemorated their independence there came an eloquent expression of the common pride in historic achievements, and the appreciation of how strongly the American republics are bound together through the course which their development has taken. The commemoration of the centenary is, according to a resolution of the conference, to take a visible form in the American products exhibition to be founded and maintained in Buenos Aires through cooperation among all the countries of America.

Turning to the work performed by the conference in the development of international administrative law, we encounter the fact that expectations are often entertained in relation to international conferences which in the nature of things are not justified. It is the purpose of a general international conference to determine a basis upon which 